ZAPISKI HistoryCZNE t. 85, 2020, z. 1, s. 187-202

ISSN 0044-1791

http://dx.doi.org/10.15762/ZH.2020.07

BARTŁOMIEJ ŁYCZAK*

(iD) https://orcid.org/0000-0002-1128-1376

\title{
ZŁotnicy w Chojnicach w XVIII Wieku
}

\begin{abstract}
Goldsmiths in Chojnice in the Eighteenth Century

The early modern goldsmithery in Chojnice (Konitz) has so far been outside the main area of scholarly research. The search in archives and libraries conducted for the purposes of the article, as well as the analysis of preserved works crafted by local masters, has therefore brought a lot of new, previously unknown information on the subject. Chojnice is a typical, small centre of goldsmithery, which remained overshadowed by Gdansk, a powerful hub of crafts located nearby. For nearly whole of the eighteenth century only a single workshop operated in the town, and a new master usually appeared only after the death of his predecessor. The research yielded information about five goldsmiths operating in Chojnice in that century, as well as one apprentice who died before becoming a master. Nearly all of them were connected by various family ties. Only a few works of art created in the Chojnice workshops were identified, but they bear the signatures of only two masters who were active in the last third of the eighteenth century. Johann Friedrich Felsch I (1744-1808) made several items for the churches nearby: an incense boat in Chojnice, a monstrance in Bysław, a monstrance base in Wiele and a reliquary cross in Tuchola, as well as a set of six spoons, currently stored in the collection of the Malbork Castle Museum. It is worth noting that his works, apart from the master's mark, bore a sign that proved he was a member of the guild of goldsmiths in Malbork. Johann Gottlieb Jantzen (1742-1772), Felsch's brother-in-law, delivered a monstrance to the church in Jeleńcz (now in Tuchola), and a frame for the worshipped statue of the Blessed Virgin Mary to the Bernardine Church in Zamarte (now missing). All these items represent an average level of artistry, and show considerable dependence on the style developed by the masters from Gdansk, where both goldsmiths active in Chojnice studied their craft.
\end{abstract}

Keywords: craft guilds; handicraft; art of the early modern period; goldsmiths; Royal Prussia

\footnotetext{
* Niezależny badacz,

@blyczak@gmail.com
}

Nadesłany 30.10.2019; Nadesłany po poprawkach 29.05.2020; Zaakceptowany 30.05.2020 
Złotnicy działający w epoce nowożytnej w mniejszych ośrodkach miejskich Prus Królewskich pozostawali w cieniu konkurencji z pobliskich dużych centrów rzemieślniczych: Gdańska, Torunia oraz Elbląga. Tamtejsze warsztaty dominowały na lokalnym rynku, ograniczając znaczenie prowincjonalnych mistrzów, po których - poza nielicznymi wyjątkami, jak Georg Platz z Malborka czy Christoph Schwartz I z Brodnicy - nie pozostała zbyt duża liczba dzieł. Chojnice do $1772 \mathrm{r}$. leżały w województwie pomorskim, gdzie stanowiły drugi po Gdańsku największy ośrodek miejski, o liczbie mieszkańców szacowanej na ok. $1500^{1}$. Po pierwszym rozbiorze Rzeczypospolitej znalazły się w zaborze pruskim. Do tej pory miejscowe złotnictwo pozostawało na uboczu zainteresowań badaczy dziejów rzemiosła artystycznego. Co wymowne, nie zostało nawet uwzględnione w opracowaniu autorstwa Eugena von Czihaka z 1908 r. ${ }^{2}$ Nazwiska przedstawicieli tej profesji, którzy otrzymali obywatelstwo Chojnic, znane są co prawda szerszemu gronu naukowemu od czasu opublikowania w 1927 r. przez Elisabeth Kloß księgi przyjęć do prawa miejskiego, a ich obecność zasygnalizował także Stanisław Gierszewski, jednak pominięci zostali całkowicie w opublikowanym przez Michała Gradowskiego i Agnieszkę Kasprzak-Miler zestawieniu mistrzów z północno-wschodniej Polski³ ${ }^{3}$ Szerszego omówienia tematyki dokonał jedynie Jacek Kriegseisen, który przedstawił informacje odnalezione w aktach przechowywanych w Archiwum Państwowym w Bydgoszczy oraz poświęcił kilka zdań Johannowi Friedrichowi Felschowi I ${ }^{4}$. Wybrane dzieła sygnowane przez tego mistrza wzmiankował ponadto Michał F. Woźniak . Przeprowadzona na potrzeby niniejszego opracowania kwerenda archiwalna w księgach metrykalnych parafii ewangelickiej w Chojnicach przechowywanych w Evangelisches Zentralarchiv w Berlinie przyniosła sporo

\footnotetext{
${ }^{1}$ Edmund Kızıк, Uwagi wstępne. Prusy Królewskie: środowisko geograficzne, administracja, demografia, [in:] Prusy Królewskie. Społeczeństwo, kultura, gospodarka, 1454-1772. Szkice z dziejów, red. Edmund Kızıк, Gdańsk 2012, s. 25.

${ }^{2}$ Eugen von CzIHAK, Die Edelschmiedekunst früherer Zeiten in Preussen, Bd. 2: Westpreussen, Leipzig 1908.

${ }^{3}$ Elisabeth KLoß, Das Bürgerbuch der Stadt Konitz von 1550-1850, Danzig 1927; zob. też Arthur Semrau, [rec.] Elisabeth Kloß, Das Bürgerbuch der Stadt Konitz von 1550-1850, Mitteilungen des Coppernicus-Vereins für Wissenschaft und Kunst zu Thorn, H. 35: 1927, s. 93; Stanisław GieRszewsKI, Struktura gospodarcza i funkcje rynkowe mniejszych miast województwa pomorskiego w XVI i XVII w., Gdańsk 1966, s. 103; Michał Gradowski, Agnieszka KasprZaK-Miler, Złotnicy na ziemiach pótnocnej Polski, cz. 1: Województwo pomorskie, kujawsko-pomorskie i warmińsko-mazurskie, Warszawa 2002.

${ }^{4}$ Jacek KRIEGSEISEN, Złotnicy w małych miastach województwa pomorskiego od połowy XVI do końca trzeciej ćwierci XVIII wieku, [in:] Klejnot w koronie Rzeczypospolitej. Sztuka zdobnicza Prus Królewskich, t. 1: Eseje, red. Czesława Betlejewska, Gdańsk 2006, s. 81-83.

${ }^{5}$ Michał F. WoźNIAK, Złotnictwo sakralne Prus Królewskich. Studium typologiczno-morfologiczne, t. 1, Toruń 2012, s. 151, 158, 186, 212.
} 
nowych, nieznanych dotąd ustaleń ${ }^{6}$. Pozwalają one rzucić nieco więcej światła na sytuację miejscowych złotników, przy czym z dwoma $\mathrm{z}$ nich można połączyć kilka rozpoznanych dzieł o przeznaczeniu sakralnym.

Na temat mistrzów czynnych w XVII w. wymienionych przez J. Kriegseisena nie udało się odnaleźć nowych, istotnych informacji. Wyjątek stanowi urodzony w Szlezwiku Johann Adolph Schultz, który otrzymał obywatelstwo Chojnic w roku $1694^{7}$. Dnia 1 sierpnia następnego roku ożenił się z Anną Dorotheą Bucholtzin, z którą miał dwie córki: Annę Barbarę (chrz. 13 I 1696)

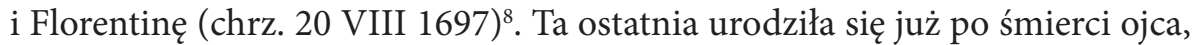
pochowanego 4 VI $1697 \mathrm{r}^{9}{ }^{9}$ Wdowa po Schultzu 20 IV 1703 r. poślubiła rymarza Friedricha Wilhelma Hilleÿa ${ }^{10}$. Zmarła w 1731 r., a jej pogrzeb odbył się dnia 10 czerwca $^{11}$.

W 1700 r. prawa miejskie uzyskał przybyły z Królewca Christian Flanßdorff (Flantzdorff, Flanzdorf) ${ }^{12}$. W Chojnicach odbyły się chrzty jego trojga dzieci pochodzących ze związku z Barbarą Haserin: Johanna Christophorusa (chrz. 1 XII 1699, poch. 13 VI 1700), Cathariny Barbary (chrz. 23 IX 1701)

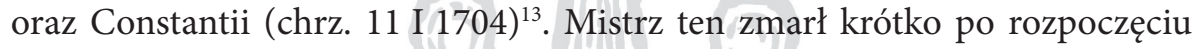
działalności rzemieślniczej. Pochowany został $20 \mathrm{~V} 1704 \mathrm{r}^{14}$

W następnym roku w mieście odnotowany został czeladnik złotniczy Johann Ernst König. Zdążył on dwukrotnie złożyć zapowiedź ślubną, jednak zmarł nie doczekawszy ani małżeństwa, ani mistrzostwa, a jego pogrzeb odbył się 10 VII $1705 r^{15}$

${ }^{6}$ Z porównania zgromadzonych wiadomości z zapisami w księdze obywateli Chojnic wynika, że wszyscy miejscowi złotnicy, którzy uzyskali prawa miejskie, byli protestantami. Wyrywkowa kwerenda w księgach metrykalnych parafii katolickiej zachowanych w Archiwum Diecezji Pelplińskiej nie przyniosła informacji o innych działających w mieście przedstawicielach tej profesji.

${ }^{7}$ E. KLOß, op.cit., s. 47.

${ }^{8}$ Evangelisches Zentralarchiv, Berlin (dalej cyt. EZAB), sygn. 6415 (Konitz. Trauungen 1641-1824), k. 41; EZAB, sygn. 6404 (Konitz. Taufen 1632-1788), k. 275, 286.

${ }^{9}$ EZAB, sygn. 6422 (Konitz. Bestattungen 1632-1832), k. 97.

${ }^{10} \mathrm{EZAB}$, sygn. 6415, k. 51. F.W. Hilleÿ pełnił też funkcję rajcy miejskiego, a pochowany został dnia 17 VI 1745 r.; EZAB, sygn. 6422, k. 210.

${ }^{11}$ EZAB, sygn. 6422, k. 181.

${ }^{12}$ E. KLoß, op.cit., s. 47. Być może spokrewniony był ze złotnikiem Philipem Flansdorffem, wzmiankowanym w $1674 \mathrm{r}$. jako ojciec chrzestny podczas uroczystości w kościele w królewieckiej dzielnicy Neurossgarten; Wolfgang Scheffler, Goldschmiede Ostpreussens. Daten, Werke, Zeichen, Berlin-New York 1983, s. 122, poz. 173b.

${ }^{13}$ EZAB, sygn. 6404, k. 305, 321, 344; EZAB, sygn. 6422, k. 104.

${ }^{14}$ EZAB, sygn. 6422, k. 114.

${ }^{15}$ Ibid., k. 119. 
Na jego miejsce przybył do Chojnic Sigmund (Siegmund, Sigißmund) Klos (Kloß). Dnia 23 XI 1705 r. jako czeladnik złotniczy poślubił Barbarę, wdowę po Christianie Flanßdorffie, z którą miał czworo dzieci: Ephraima (chrz. 22 VII 1706), Johanna (chrz. 15 VII 1708), Benjamina Sigmunda (chrz. 17 XI 1710) i Dorotheę Florentinę (chrz. 21 VI 1713) ${ }^{16}$. Co ciekawe, jego nazwisko nie występuje $\mathrm{w}$ spisie obywateli miasta. $\mathrm{W}$ przeciwieństwie do poprzedników, S. Klos prowadził swój zakład przez kilkadziesiąt lat. Pochowany został 13 IX 1739 r., a w księdze pogrzebów określony został wówczas jako „stary złotnik"17.

Kolejnym mistrzem czynnym w Chojnicach był Martin Korn (ur. 16 IX 1697), syn grudziądzkiego złotnika Nicolausa Korna II i Christiny ${ }^{18}$. Naukę zawodu odbył w toruńskim warsztacie Johanna von Hausena II. Na pięcioletni termin zapisany został podczas kwartału wielkanocnego $1713 \mathrm{r}$., a wyzwoliny nastąpiły w czasie kwartału świętojańskiego roku $1718^{19}$. Obywatelem Chojnic został w $1734 \mathrm{r}^{20}$, wówczas też, dnia 9 marca poślubił Catharinę Bögin, wdowę po asesorze sądowym Danielu Semrau ${ }^{21}$. Wiadomo, że M. Korn sprawował funkcję ławnika miejskiego, a ponadto był witrykiem kościoła pw. Świętej Trójcy. Wymieniony został także wśród ofiarodawców drewna na rzecz odbudowy plebanii kościoła farnego ${ }^{22}$. Pierwsza żona złotnika pochowana została 26 V 1739 r. w wieku 63 lat ${ }^{23}$. Dnia 7 II 1742 r. ponownie się ożenił, z Evą Christiną (ur. 24 XII 1721), córką Friedricha Wilhelma Hilleÿa i Anny Dorothei, wdowy po wspomnianym J.A. Schultzu ${ }^{24}$. Wiadomo, że wówczas mistrz zamieszkiwał kamienicę przy południowej pierzei Rynku ${ }^{25}$. Martin Korn zmarł w następnym roku. Jego pogrzeb odbył się dnia $31 \mathrm{marca}^{26}$. Eva Christina prze-

${ }^{16}$ EZAB, sygn. 6404, k. 364, 374, 386, 400; EZAB, sygn. 6415, k. 53.

${ }^{17}$ EZAB, sygn. 6422, k. 203.

${ }^{18}$ Bartłomiej ŁyCzAK, Artyści grudziądzcy w XVII i XVIII wieku. Czesść 1: Złotnicy, Rocznik Grudziądzki, t. 26: 2018, s. 57.

${ }^{19}$ Ibid., s. 58, 68. J. von Hausen II (1676-1753) został mistrzem w Toruniu w 1701 r.; zob. Adam Kucharski, Hausen Jan II (młodszy) von, [in:] Toruński słownik biograficzny, t. 5, red. Krzysztof Mikulski, Toruń 2007, s. 50-52; B. ŁyCZAK, op.cit., s. 58.

${ }^{20}$ E. KLOß, op.cit., s. 56.

${ }^{21}$ EZAB, sygn. 6415, k. 100.

${ }^{22}$ Liber Regestrorum in quo proventus ecclesiae parochialis Conecensis tum quoque fructus praepositum eiusdem ecclesiae concernentes ac alia pro meliori successorum informatione memoriae digna fideliter suis locis annotantur, Anno Domini 1738 die prima decembris, opr. i tł. Adam Szweda, red. Anna Czapczyk, Barbara Zagórska, Chojnice 2001, s. 120-121.

${ }^{23}$ EZAB, sygn. 6422, k. 202.

${ }^{24}$ EZAB, sygn. 6404, k. 477; EZAB, sygn. 6415, k. 110.

${ }^{25}$ Andrzej Groth, Brandgeschädigte in der Stadt Konitz 1742, Altpreußische Geschlechterkunde. Neue Folge, Bd. 34: 2004, s. 246.

${ }^{26}$ EZAB, sygn. 6422, k. 207. 
żyła męża o ponad dwie dekady. Dnia 30 I 1744 r. poślubiła piekarza Johanna Friedricha Felscha ${ }^{27}$, a pochowana została 10 VII 1766 r. $^{28}$

W następnym ćwierćwieczu nie pojawiła się żadna wzmianka na temat działającego w Chojnicach złotnika, przedstawiciel tej profesji nie występuje także w spisie mieszkańców z roku $1749^{29}$. Dopiero w 1768 r. obywatelstwo miasta otrzymał Johann Friedrich Felsch $\mathrm{I}^{30}$. Urodził się w Chojnicach dnia 27 XI 1744 r., jego rodzicami byli wzmiankowani piekarz Johann Friedrich Felsch i Eva Christina z domu Hilleÿ, wdowa po M. Kornie ${ }^{31}$. Podczas kwartału wielkopostnego 1761 r. Felsch został zapisany na sześcioletni termin w gdańskim warsztacie Hieronymusa Holla III $^{32}$. Już po powrocie do Chojnic, 7 VIII 1770 r. poślubił Marię Susannę Hekertin, córkę miejscowego apteka$\mathrm{rza}^{33}$. Para miała sześcioro dzieci: Johanna Friedricha II (ur. 12 V 1771), Marię Elisabeth (ur. 4 XII 1773, zm. 18 XI 1817), Annę Dorotheę (ur. 17 XII 1775), Carla Ludwiga (ur. 3 V 1781), Daniela Gotthilfa (ur. 13 XII 1782) oraz Annę Dorotheę (ur. 6 X 1784) ${ }^{34}$. Pierwsza małżonka złotnika zmarła 20 IV 1790 r. $^{35}$, po raz drugi ożenił się on 19 XI 1793 r. z 28-letnią Marią Elisabeth, córką Andreasa Rotzolla ${ }^{36}$. Felsch zmarł 9 X 1808 r., przy wpisie w księdze zgonów określony został wówczas jako złotnik, handlarz zbożem i zwierzchnik kościoła ewangelickiego ${ }^{37}$.

Zapewne najwcześniejszym zachowanym dziełem wywodzącym się $\mathrm{z}$ warsztatu J. F. Felscha jest łódka na kadzidło z kościoła pw. Ścięcia św. Jana Chrzciciela w Chojnicach (il. 1).

${ }^{27}$ EZAB, sygn. 6415, k. 112.

${ }^{28}$ EZAB, sygn. 6422, k. 246.

${ }^{29}$ Andrzej Groth, Chojnice w 1749 roku, Teki Gdańskie, t. 4: 2002, s. 215-229.

${ }^{30}$ E. KLOß, op.cit., s. 63.

${ }^{31}$ EZAB, sygn. 6404, k. 648. W 1749 r. J. F. Felsch, starszy cechu piekarskiego posiadał kamienicę w południowej pierzei Rynku, pochowany został 25 I 1767 r.; EZAB, sygn. 6422, k. 247; A. Groth, Chojnice w 1749 roku, s. 217.

${ }^{32}$ Archiwum Państwowe w Gdańsku (dalej cyt. APG), sygn. 300C/1966 (Goldschmiedezunft in Danzig, Lehrlings Einschreibebuch, 1588-1830), k. 221v. Hieronymus Holl III (1709-1795) został mistrzem w 1741 r., a w gdańskim cechu działał do roku 1780; zob. Jacek KriegSeISEN, Słownik złotników gdańskich czynnych w latach 1700-1816, [in:] „...tyżek srebrnych dwa tuziny". Srebra domowe w Gdańsku 1700-1816, red. Jacek KrIEgSEISEN, Ewa BARYLEWSKA-SZYMAŃsKa, Gdańsk 2007, s. 171.

${ }^{33}$ EZAB, sygn. 6415, k. 142. Według spisu obywateli z 1772 r. żoną Felscha była Euphrosina z domu König; zob. Andrzej Groth, Ausschnitt aus der Bewohnerschaft der Stadt Konitz für 1771/1772, Altpreußische Geschlechterkunde. Neue Folge, Bd. 34: 2004, s. 239.

${ }^{34} \mathrm{EZAB}$, sygn. 6404, k. 819, 863, 887, 939, 952, 970; EZAB, sygn. 6422, k. 611.

${ }^{35}$ EZAB, sygn. 6422, k. 390.

${ }^{36}$ EZAB, sygn. 6415, k. 216.

${ }^{37}$ EZAB, sygn. 6422, k. 552. Według księgi przyjęć do prawa miejskiego Chojnic Felsch zmarł w roku 1809; zob. E. KLoß, op.cit., s. 63. 
Opatrzona została umieszczonymi na kryzie stopy grawerowanymi inicjałami IFF, połączonymi już z Felschem przez J. Kriegseisena, a także liczbą 13,

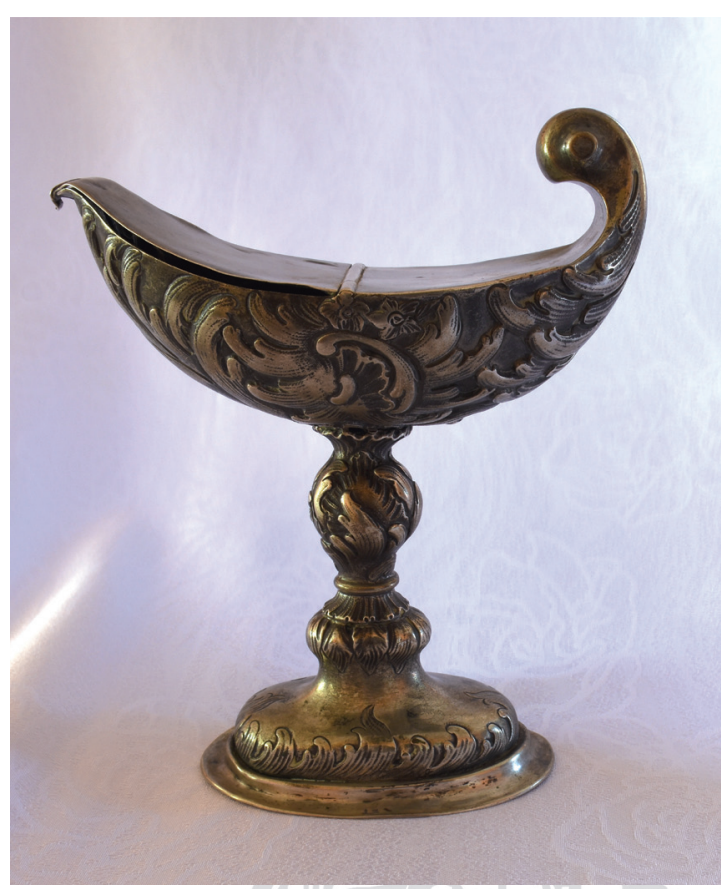

Il. 1. Johann Friedrich Felsch I, łódka na kadzidło, kościół pw. Ścięcia św. Jana Chrzciciela w Chojnicach, 1768-1773. Fot. B. Łyczak określającą próbę kruszcu ${ }^{38}$. Według inwentarza sreber parafialnych z 1773 r. dzieło powstało $\mathrm{z}$ przetopienia starych sprzętów przekazanych złotnikowi w tym celu 3 VII 1768 r. ${ }^{39}$ Wówczas sprawione zostały także nowe trybularz i lampa, prawdopodobnie również wykonane przez Felscha, obecnie niestety niezachowane. Łódka na kadzidło wsparta jest na owalnej, silnie wysklepionej stopie z szeroką kryzą. U dołu ozdobiona została trybowanym, fakturowanym płomienistym akantem, u góry zaś pojedynczymi, fakturowanymi liśćmi, ujmującymi gładką przestrzeń na przejściu płaszcza w szyjkę. $\mathrm{Z}$ kolei trzon i zaopatrzo-

ny w wolutowy uchwyt korpus w całości pokryte zostały repusowanym, fakturowanym ornamentem rocaille, jak zauważył M. F. Woźniak, dość chaotycznie rozmieszczonym.

${ }^{38}$ Chojnice, Czersk i okolice, opr. Piotr PaŁamarz, Jerzy T. Petrus (Katalog zabytków sztuki w Polsce, t. 11: Dawne województwo bydgoskie, z. 5), Warszawa 1979, s. 17 (tu znak odczytany jako IEE); Michał Gradowski, Magdalena Pielas, Katalog złotnictwa w zbiorze dokumentacji specjalistycznej Krajowego Ośrodka Badań i Dokumentacji Zabytków w Warszawie, cz. 1, Warszawa 2006, s. 87, nr 61/7; Barbara ZAGóRsKA, Losy złotnictwa parafii farnej w Chojnicach na przestrzeni dziejów w świetle źródeł historycznych, [in:] Chojnicka bazylika świadectwem wieków. Materiały z sesji naukowej zorganizowanej z okazji jubileuszu 10-lecia nadania chojnickiej Farze tytułu Bazyliki Mniejszej, red. Hanna RząsKa, Chojnice 2003, s. 43, 46; J. Kriegseisen, Złotnicy w małych miastach, s. 83; M. F. WoźNIAK, op.cit., s. 158, 212; idem, Złotnictwo sakralne Prus Królewskich. Studium typologiczno-morfologiczne, t. 2: Ilustracje, Toruń 2012, il. 403.

${ }^{39}$ Liber Regestrorum, s. 140-141. 
Kolejne cztery znane wyroby pochodzące $z$ warsztatu Felscha sygnowane są już puncą z inicjałami F/IF w trójliściu (il. 2a ${ }^{40}$. Co istotne, na wszystkich tych dziełach widnieje także znak miejski Malborka ${ }^{41}$. Oznacza to, że chojnicki mistrz należał do tamtejszego cechu złotniczego jako majster zamiejscowy, „inkorporowany”42. Dawało mu to możliwość oficjalnego zapisywania i wyzwalania uczniów oraz przyjmowania pracowników, co następnie potwierdzane było przez wystawienie odpowiednich zaświadczeń, respektowanych na terenie całej Europy. Warto dodać, że w warsztacie Felscha odnotowano czeladnika w latach 1776 i $1777^{43}$. Zamiejscowy mistrz musiał oczywiście opłacać składki, które jednak zwyczajowo były niższe niż w przypadku regularnych członków. Ponadto najczęściej zakazywano mu pracy w mieście stanowiącym siedzibę cechu.
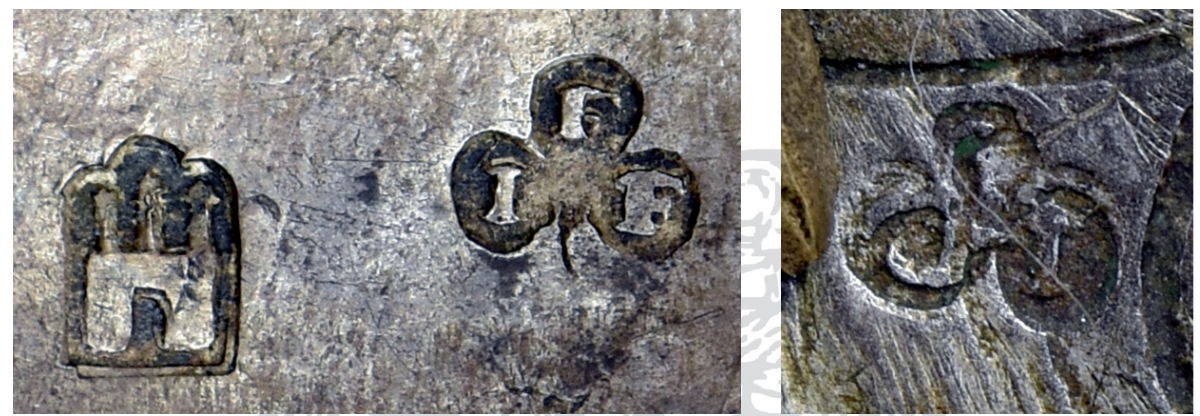

Il. 2. Znaki złotnicze na wyrobach z chojnickich warsztatów: a. warsztatowy Johanna Friedricha Felscha I i miejski Malborka;

b. warsztatowy Johanna Gottlieba Jantzena. Fot. B. Łyczak

Monstrancja z kościoła pw. Przemienienia Pańskiego w Bysławiu wykonana została zapewne ok. 1770 r. (il. 3) ${ }^{44}$. Poprzez stylistyczną zależność od wyrobów gdańskich, na którą uwagę zwrócił już M. F. Woźniak, zdradza tamtejszą edukację Felscha ${ }^{45}$. Dzieło, niemal w całości pozłocone, osadzone zostało

${ }^{40}$ M. Gradowski, A. Kasprzak-Miler, op.cit., s. 170, poz. M43 (jako znak działającego ok. połowy XVIII w. „Monogramisty F/IF” z Malborka).

${ }^{41}$ Michał Gradowski, Znaki na srebrze. Znaki miejskie i państwowe używane na terenie Polski w obecnych jej granicach, Warszawa 2010, s. 134, nr 3.

${ }^{42}$ Por. Stanisław Herbst, Toruńskie cechy rzemieślnicze. Zarys przeszłości, Toruń 1933, s. $32-33$.

${ }^{43}$ Andrzej Groth, Małe miasta pomorskie w latach 1772-1806, Słupsk 2009, s. 143.

${ }^{44}$ Tuchola $i$ okolice, opr. Beata BiedrońskA-SŁotA, Irena KonopkA (Katalog zabytków sztuki w Polsce, t. 11: Dawne województwo bydgoskie, z. 17), Warszawa 1979, s. 2, il. 60; M. Gradowski, M. Pielas, op.cit., s. 52, nr 46/1 (w obu publikacjach jako dzieło „Monogramisty F/IF”); M. F. WoźNIAK, Złotnictwo sakralne, t. 1, s. 158; idem, Złotnictwo sakralne, t. 2, il. 293.

${ }^{45}$ Idem, Złotnictwo sakralne, t. 1, s. 158. 
na masywnej stopie z uskokiem i wysokim, lekko wklęsłym cokolikiem ozdobionym oszczędną dekoracją w postaci żłobień i trybowanych, rocaillowych

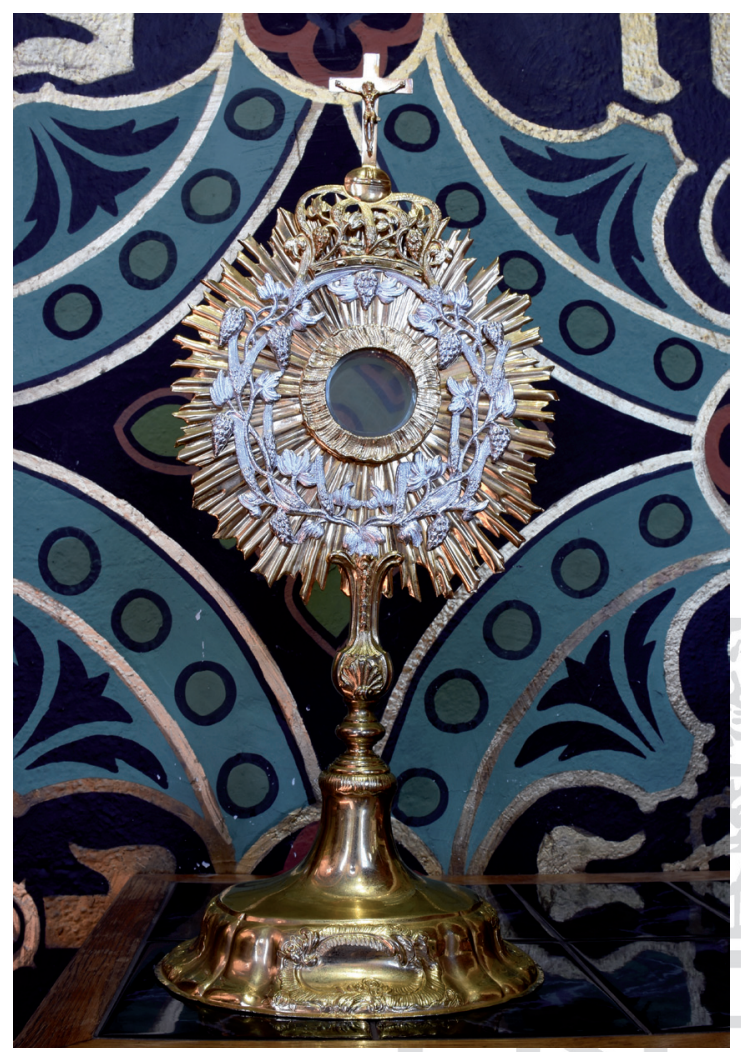

Il. 3. Johann Friedrich Felsch I, monstrancja, kościół pw. Przemienienia Pańskiego w Bysławiu, ok. 1770 r. Fot. B. Łyczak kartuszy. Szyjka jest gładka, a nodus zredukowany do pierścienia. Powyżej znajduje się smukły, tralkowy trzon rozdwajający się u góry i zdobiony palmetą. Reservaculum ujęte zostało otokiem $\mathrm{z}$ fakturowanego ornamentu rocaille. W partii glorii uderza skontrastowanie twardej, wyciętej z jednego arkusza blachy tarczowej formy promieni z nałożoną na nie pozbawioną złocenia i delikatnie prowadzoną wicią winorośli zwieńczoną ażurową koroną z dość dużym krzyżem na szczycie. Podobny koncept zastosował gdański złotnik Johann Gottlieb Schlaubitz w monstrancji w Bartągu koło Olsztyna, wykonanej w $1769 \mathrm{r}^{46}$ W całościowym odbiorze dzieło Felscha bliskie jest

${ }^{46}$ Ibid., s. 150; idem, Złotnictwo sakralne, t. 2, il. 269; idem, Dwie monstrancje osiemnastowieczne w bydgoskiej katedrze, [in:] Kościół katedralny w Bydgoszczy. Studia, red. Aleksander Jankowski, Dariusz Karczewski, Bydgoszcz 2018, s. 88, 93, il. 11. Michał F. Woźniak zasugerował, że w Chojnicach wykonana została monstrancja przechowywana obecnie w świątyni pocysterskiej w Koronowie, zbliżona formalnie do dzieła z Bartąga, choć dużo słabszej klasy artystycznej; zob. M. F. WoźNıAK, Dwie monstrancje, s. 93. Według inskrypcji ufundował ją w 1790 r. (a nie - jak podał M. F. Woźniak - w 1750 r.) opat Antoni Jan Chrząstowski dla koronowskiego kościoła parafialnego pw. św. Andrzeja. Dzieło w starszej literaturze przedmiotu przypisywane było toruńskiemu warsztatowi Daniela Clausena I; zob. E. von CzıHAK, op.cit., s. 138, nr 113.6; Emanuel ОкоŃ, Zabudowa klasztoru cysterskiego w Koronowie w XVIII stuleciu, [in:] Conservatio est aeterna creatio. Ksiega dedykowana prof. Janowi Tajchmanowi, red. Janusz KraWCZYK, Toruń 1999, s. 244-245. Znaki wybite na sprzęcie są mało czytelne, odbiegają jednak zarówno od cech używanych przez J. F. Felscha I, jedynego działającego wówczas w Chojnicach złotnika, jak i od tych stosowanych przez D. Clausena. 
także ostensorium z Łęgowa, autorstwa jego nauczyciela, H. Holla III ${ }^{47}$. Podobnie uformowane zostały ich stopy, a trzony są wręcz identyczne.

Analogicznie rozwiązana została także stopa dorobiona przez chojnickiego złotnika do monstrancji w kościele pw. św. Mikołaja w Wielu ${ }^{48}$. Nieco niezgrabnie wykonana dekoracja składająca się z ornamentu rocaille $\mathrm{z}$ dodanymi niewielkimi kwiatkami pojawiła się w tym wypadku także na szyjce.

Felsch sygnował ponadto krzyż relikwiarzowy w kościele pw. Bożego Ciała w Tucholi (il. 4$)^{49}$. Dzieło osadzone zostało na owalnej stopie w całości pokrytej trybowanym ornamentem rocaille. Jej lekko wydęty płaszcz przypomina rozwiązanie zastosowane przez gdańskiego złotnika Christiana von Hausena w monstrancji z Chojnic, wykonanej ok. roku $1760^{50}$. Nodus zredukowany został do pierścienia, na zakończeniu trzonu zaś umieszczono dekoracyjną palmetę. Ramiona krzyża są lekkie, stosunkowo wąskie, $\mathrm{z}$ treflowymi zakończeniami. Przypominają wyroby warsztatów gdańskich, które jednak charakteryzowały się więk-

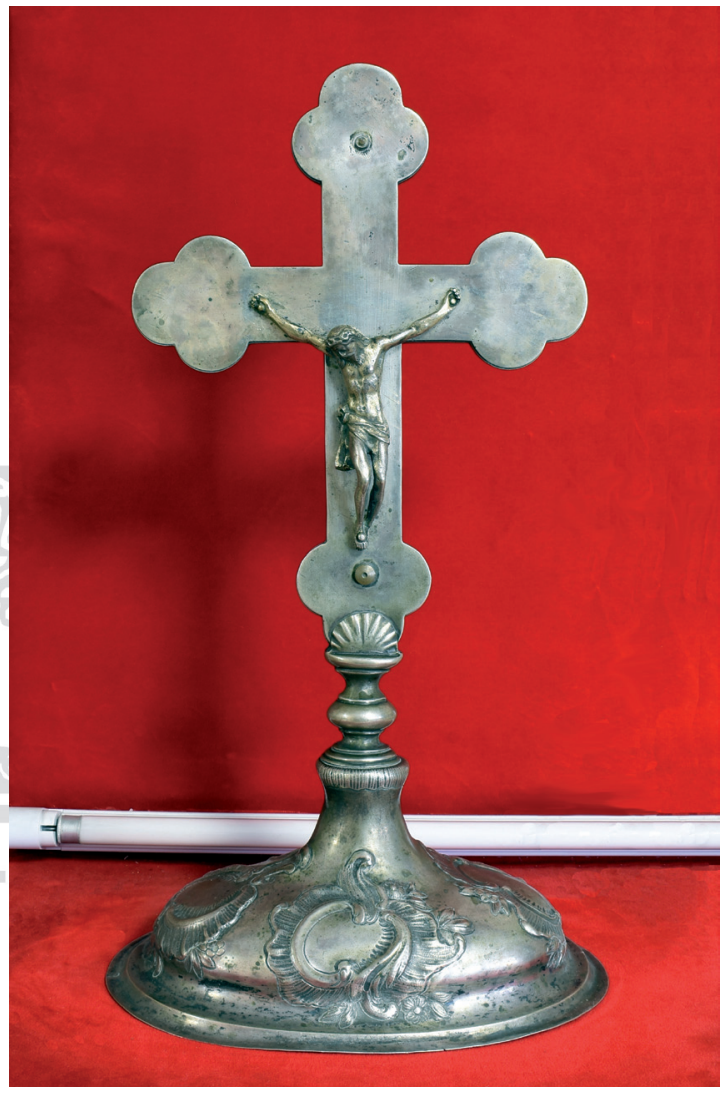

4. Johann Friedrich Felsch I, krzyż relikwiarzowy, kościół pw. Bożego Ciała w Tucholi, 1770-1780. Fot. B. Łyczak

${ }^{47}$ M. F. WoŹNIAK, Złotnictwo sakralne, t. 1, s. 153-154; idem, Złotnictwo sakralne, t. 2, il. 283.

${ }^{48}$ Chojnice, Czersk i okolice, s. 70 (tu znak błędnie odczytany jako EIF); M. Gradowski, M. Pielas, op.cit., s. 851, nr 652/1 (tu jako dzieło „Monogramisty F/IF”); M. F. WoźNiaK, Złotnictwo sakralne, t. 1, s. 151.

${ }^{49}$ Tuchola i okolice, s. 27, il. 72 (nieatrybuowany); M. Gradowski, M. Pielas, op.cit., s. 807, nr 615/4 (tu jako dzieło „Monogramisty F/IF”); M. F. WoźNIAK, Złotnictwo sakralne, t. 1, s. 186.

${ }^{50}$ M. F. WoźNIAK, Złotnictwo sakralne, t. 1, s. 154-155; idem, Złotnictwo sakralne, t. 2, il. 284 . 
szymi rozmiarami i jeszcze smuklejszymi proporcjami ${ }^{51}$. Na rewersie tucholskiego dzieła przytwierdzona jest odlana figurka Chrystusa, z kolei na awersie widnieje miejsce po usuniętym okulusie.

Dopełnieniem korpusu znanych dzieł J. F. Felscha jest komplet sześciu łyżek z punktowanymi inicjałami FR, przechowywany w Muzeum Zamkowym w Malborku ${ }^{52}$.

Opublikowane w 1939 r. wypisy z kroniki parafii pw. św. Wojciecha w Sadkach zawierają informacje o jeszcze jednym zleceniu realizowanym przez omawianego złotnika ${ }^{53}$. W wyniku włamania do kościoła w 1797 r. skradzione zostały liczne elementy wyposażenia, w tym monstrancja, puszka na komunikanty i dwa relikwiarze. W następnym roku, 22 listopada przekazano J. F. Felschowi 34 srebrne plakietki wotywne z ołtarza Najświętszej Marii Panny, lampę wieczną oraz tackę na ampułki i zlecono przelanie ich, a z uzyskanego w ten sposób materiału wykonanie nowej monstrancji. Koszt robocizny, który wynieść miał ok. 46 talarów, pokryto ze składek wiernych zamieszkałych w miejscowościach należących do parafii. Wśród sreber obecnie znajdujących się w Sadkach nie ma niestety omawianego dzieła.

Przez krótki czas równolegle z J. F. Felschem działał pochodzący z Gdańska Johann Gottlieb Jantzen. Najprawdopodobniej był on synem Johanna i Elisabeth Jantzenów ochrzczonym - tylko pierwszym imieniem - 24 III $1742 \mathrm{r}$. w tamtejszym kościele Mariackim ${ }^{54}$. Naukę rzemiosła odbył w gdańskim warsztacie Johanna Gottfrieda Schlaubitza, do którego zapisany został podczas kwartału zielonoświątkowego 1759 r. na siedem i pół roku ${ }^{55}$. Obywatelstwo Chojnic uzyskał w roku $1770^{56}$. Jego żoną była Eva Christina (ur. 19 XII 1750), siostra Johanna Friedricha Felscha I ${ }^{57}$. Małżeństwo trwało bardzo krótko, gdyż już w 1772 r. mistrz opuścił Chojnice, porzucając żonę. Ich jedyny syn, Johann

${ }^{51}$ Krzyże relikwiarzowe z Gdańska mają wysokość ok. $50-60 \mathrm{~cm}$, podczas gdy ich toruńskie odpowiedniki, a także wyrób Felscha 35-45 cm; zob. M. F. WoźnIAK, Złotnictwo sakralne, t. 1, s. 184.

${ }^{52} \mathrm{Nr}$ inw. MZM/MZC/575/1-6. Za informację na temat łyżek dziękuję Bartłomiejowi Butrynowi z Muzeum Zamkowego w Malborku.

${ }^{53} Z$ dziejów naszego kościoła parafialnego, cz. 5, Rocznik Parafialny Parafii Sadkowskiej, nr 5-6: 1939, s. 2; Sławomir Kamosıński, Sadki. Dzieje i współczesność, Bydgoszcz 2009, s. 40. Za udostępnienie reprodukcji artykułu z „Rocznika Parafialnego Parafii Sadkowskiej” dziękuję dr. hab. Sławomirowi Kamosińskiemu z Uniwersytetu Kazimierza Wielkiego w Bydgoszczy.

${ }^{54}$ APG, sygn. 354/323 (Marienkirche in Danzig - Taufen, 1740-1752), s. 34.

${ }^{55}$ APG, sygn. 300C/1966, k. 230v; J. Kriegseisen, Słownik złotników, s. 184. J. G. Schlaubitz (1707-1771) został mistrzem w $1733 \mathrm{r}$.

${ }^{56}$ E. KLOß, op.cit., s. 63.

${ }^{57}$ EZAB, sygn. 6404, k. 685. 
Ephraim urodził się 10 I 1773 r. ${ }^{58}$ Kilkanaście dni później Eva Christina Jantzen zmarła, została pochowana 24 stycznia $^{59}$. Dalszych losów złotnika nie udało się dotąd ustalić.

Mimo tylko dwuletniej działalności w Chojnicach J. G. Jantzen pozostawił po sobie dwa znane dzieła, sygnowane znakiem warsztatowym z jego inicjałami I/GI umieszczonymi w trójliściu (il. 2b). Pierwszym jest monstrancja przechowywana obecnie w kościele pw. Bożego Ciała w Tucholi, a przeniesiona tam ze świątyni pw. Chrystusa Króla w pobliskim Jeleńczu, gdzie znajdowała się jeszcze w latach siedemdziesiątych XX w. (il. 5) ${ }^{60}$.

Dzieło osadzone jest na masywnej, wysokiej stopie o miękkich formach, dekorowanej rocaillem. $\mathrm{Z}$ tego ornamentu w całości uformowane zostały trzon oraz plastyczna, złocona dekoracja aplikowana na awersie owalnej, promienistej glorii zwieńczonej niewielkim krzyżem. Rewers glorii ozdobiony został $\mathrm{z}$ kolei rytowanym rocaillem. Sprzęt wykazuje inspiracje twórczością J. G. Schlaubitza, przy czym Jantzen nie dorównywał swojemu nauczycielowi skalą talentu i finezją w operowaniu

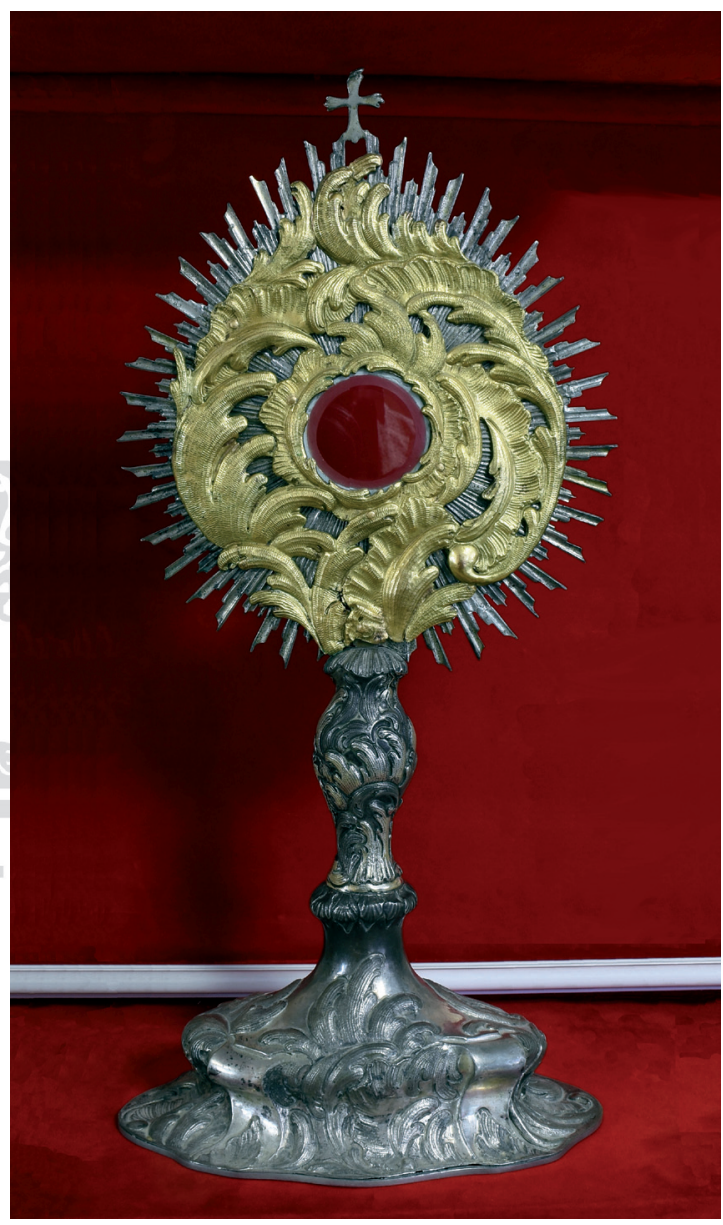

Il. 5. Johann Gottlieb Jantzen, monstrancja, kościół pw. Bożego Ciała w Tucholi (pierwotnie kościół pw. Chrystusa Króla w Jeleńczu), 1770-1772. Fot. B. Łyczak

${ }^{58}$ Ibid., k. 831.

${ }^{59}$ EZAB, sygn. 6422, k. 260.

${ }^{60}$ Tuchola i okolice, s. 9, il. 62; M. Gradowski, M. Pielas, op.cit., s. 806, nr 615/1 (tu znak warsztatowy odczytany jako I/CI); M. F. WoźNIAK, Złotnictwo sakralne, t. 1, s. 155, 158 (tu jako dzieło J. F. Felscha I). 
rokokowymi formami. Próba zespolenia bryły z dekoracją ornamentalną, jak nieudolnie zamarkowany skręt rocaillowego trzonu, czy chęć zasugerowania

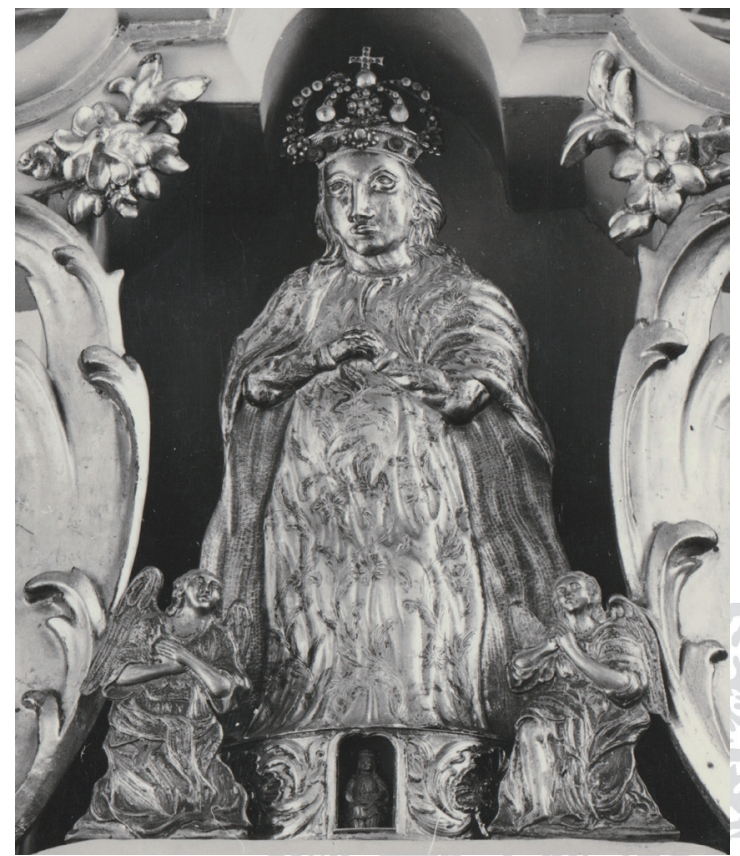

Il. 6. Johann Gottlieb Jantzen, oprawa rzeźby Najświętrodzenia NMP w Zamartem), 1770 r. Fot. za: Chojnice, Czersk i okolice, opr. Piotr PaŁamarz, Jerzy T. Petrus (Katalog zabytków sztuki w Polsce, t. 11: Dawne województwo bydgoskie, z. 5), Warszawa 1979, il. 204 szej Marii Panny, zaginiona (pierwotnie kościół pw. Na-

płynnego przenikania się poszczególnych elementów sprzętu nie wytrzymują porównania $\mathrm{z}$ analogicznymi rozwiązaniami w mistrzowski sposób zastosowanymi przez gdańskiego złotnika, chociażby w monstrancjach w kościele w Kielnie koło Gdańska (1759), farze (obecnie katedrze) w Bydgoszczy (1760) - według ustaleń M. F. Woźniaka pierwotnie przeznaczona dla tamtejszych bernardynów, nie zaś jezuitów - czy świątyni w Bartagu (1769) ${ }^{61}$.

Drugim ze znanych dzieł opatrzonych znakiem J.G. Jantzena jest oprawa dla otoczonej kultem już w średniowieczu niewielkiej drewnianej rzeźby Najświętszej Marii Panny z bernardyńskiego (obecnie parafialnego zarządzanego przez karmelitów bosych) kościoła pw. Narodzenia NMP w Zamartem (il. 6) ${ }^{62}$.

Dzieło powstało w $1770 \mathrm{r}$. jako fundacja miejscowego gwardiana Antoniego Czarnowskiego. W 1983 r. skradziono je ze świątyni i do dziś nie zostało odnalezione. Relikwiarz ma formę pełnoplastycznej figury Najświętszej Marii Panny adorowanej przez dwa anioły. W cokole głównego wyobrażenia znajduje się niewielka nisza mieszcząca czczony wizerunek, ujęta trybowanymi ornamentami rocaille. Maria wyobrażona została w pozycji stojącej, w długiej suk-

${ }^{61}$ M. F. WoźNIAK, Złotnictwo sakralne, t. 1, s. 150-153; idem, Złotnictwo sakralne, t. 2, il. 269-270, 276; idem, Dwie monstrancje, s. 75-76, 85-88, il. 5, 8, 11.

${ }^{62}$ Kamil KantaK, Kronika bernardynów zamarckich, Zapiski Towarzystwa Naukowego w Toruniu, t. 6: 1925, nr 12, s. 185; Chojnice, Czersk i okolice, s. 77, il. 204; Lech ŁвIк, Z zamierzchlych dziejów sanktuarium Maryjnego w Zamartem koło Chojnic (XV-XVIII wiek), Rocznik Gdański, t. 60: 2000, z. 2, s. 24, il. 3; M. Gradowski, M. Pielas, op.cit., s. 890, nr 689/8. 
ni z wycięciem na dekolcie oraz zarzuconym na ramiona płaszczu. Jej strój pokryty jest rytowaną dekoracją w postaci wici kwiatowej. Dłonie ma złączone w geście modlitewnym, na głowie zaś bogato kameryzowaną koronę. Klęczące po bokach Matki Bożej anioły ubrane są w długie szaty, układające się w nieregularne fałdy. Składają ręce na piersiach i zwracają głowy w kierunku głównej postaci kompozycji.

Tego typu wyroby stanowiły w epoce nowożytnej rzadkość na terenie Prus Królewskich. Znane są dwie figurki klęczących aniołów, wykonane w $1728 \mathrm{r}$. dla kościoła pw. św. Tomasza Apostoła w Nowym Mieście Lubawskim, będące zapewne dekoracją tabernakulum ${ }^{63}$. Niewiele powstało także relikwiarzy mówiących - zdecydowanie dominowały ostensoria oraz krzyże ${ }^{64}$.

Złotnictwem zajmowali się także dwaj synowie J. F. Felscha I. Urodzony 12 V 1771 r. Johann Friedrich II obywatelstwo Chojnic uzyskał w roku $1805^{65}$. W tym samym roku, 2 sierpnia, poślubił 19-letnią Barbarę Elisabeth Gördel z Dunkelshagen ${ }^{66}$. W swoim rodzinnym mieście przebywał do 1819 r., kiedy wyjechał do Koszalina ${ }^{67}$. Daniel Gotthilf Felsch (ur. 13 XII 1782) otrzymał prawa miejskie Chojnic w roku 1808, a 20 kwietnia tego roku ożenił się z Marią Elisabeth Frensdorf ${ }^{68}$. Złotnik zmarł 5 II 1813 r. $^{69}$

Z przedstawionych informacji wynika, że w XVIII w. Chojnice stanowiły niewielki ośrodek złotniczy, w którym działał zazwyczaj pojedynczy warsztat. Jak zauważył J. Kriegseisen, nie może być zatem mowy o funkcjonowaniu na miejscu osobnego cechu, co potwierdza akces J. F. Felscha I do odpowiedniej organizacji w Malborku ${ }^{70}$. Na obecnym etapie badań trudno jednoznacznie ocenić, czy stan ten wynikał z odgórnego limitu wprowadzonego przez władze miejskie, w każdym razie nowy mistrz pojawiał się dopiero po śmierci swojego poprzednika. Wyjątek od tej reguły stanowił M. Korn, który rozpoczął działalność jeszcze za życia S. Klosa, choć ten ostatni był już wówczas niewątpliwie zaawansowany wiekowo i potencjalnie niezdolny do pracy. Ponadto po trwającym 25 lat okresie, w którym nie odnotowano w Chojnicach żadnego złotnika,

${ }^{63}$ Katarzyna KrupsKa, Bartłomiej ŁyCzAK, Kontrakty między ks. Janem Ewertowskim a toruńskim złotnikiem Jacobem Weintraubem na wykonanie sreber do kościoła św. Tomasza Apostoła w Nowym Mieście Lubawskim z lat 1711-1728, Biuletyn Historii Sztuki, t. 79: 2017, z. 1, s. 144, il. 10-11. Wykonane w 1650 r. przez Johanna Christiana Bierpfaffa dekoracje nastawy ołtarzowej w Kaplicy Matki Bożej Częstochowskiej na Jasnej Górze powstały jeszcze w Warszawie, przed przenosinami mistrza do Torunia; zob. M. F. WoźnıAK, Złotnictwo sakralne, t. 1, s. 227.

${ }^{64}$ Ibid., s. 171.

${ }^{65}$ EZAB, sygn. 6404, k. 819; E. KLOß, op.cit., s. 71.

${ }^{66}$ EZAB, sygn. 6415, k. 256.

${ }^{67}$ E. KLOß, op.cit., s. 71.

${ }^{68}$ EZAB, sygn. 6404, k. 952; EZAB, sygn. 6415, k. 262; E. KLOß, op.cit., s. 71.

${ }^{69}$ EZAB, sygn. 6422, k. 571.

${ }^{70}$ J. Kriegseisen, Złotnicy $w$ małych miastach, s. 81-82. 
w latach 1770-1772 funkcjonowały równolegle pracownie J. F. Felscha I oraz jego szwagra J. G. Jantzena. Analiza ksiąg metrykalnych wykazała, że niemal wszyscy miejscowi złotnicy byli połączeni ze sobą więzami rodzinnymi, w których centrum znajdowały się dwie kobiety. Eva Christina z domu Hilleÿ, córka wdowy po Johannie Adolphie Schultzu, była żoną Martina Korna, a z drugiego małżeństwa matką Johanna Friedricha Felscha I oraz teściową Johanna Gottlieba Jantzena. Natomiast Barbara Haserin była najpierw żoną Christiana Flanßdorffa, następnie zaś Sigmunda Klosa. Te zawiłe związki dowodzą, że najkorzystniejszy sposób na wejście w posiadanie wyposażenia warsztatu rzemieślniczego, tj. wszelkiego rodzaju narzędzi i form odlewniczych, a także zbioru różnego rodzaju wzorników graficznych i rysunkowych, prowadził przez odpowiednio zaaranżowane małżeństwo.

Nielicznie zachowane dzieła z chojnickich warsztatów, które udało się zidentyfikować, cechują się przeciętną wartością artystyczną. Wyroby sygnowane przez J. F. Felscha I oraz J. G. Jantzena wykazują całkowitą zależność od rozwiązań stosowanych przez mistrzów czynnych w Gdańsku, gdzie obaj odbyli naukę. Zasięg oddziaływania omówionych w tekście twórców był niewielki, ograniczony jedynie do najbliższych okolic miasta. Potwierdza to absolutnie dominującą pozycję, jaką zajmowało nadmotławskie centrum rzemieślnicze zarówno pod względem liczby bezpośrednio realizowanych zleceń, jak i rozpowszechniania konkretnych rozwiązań stylistycznych na terenie województwa pomorskiego.

\section{BIBLIOGRAFIA}

Biedrońska-Słota, Beata and Irena Konopka, eds. Tuchola i okolice. Warszawa: Polska Akademia Nauk, Wydawnictwa Artystyczne i Filmowe, 1979.

Czihak von, Eugen. Die Edelschmiedekunst früherer Zeiten in Preussen, vol. 2: Westpreussen. Leipzig: Verlag von Karl W. Hiersemann, 1908.

Gierszewski, Stanisław. Struktura gospodarcza i funkcje rynkowe mniejszych miast województwa pomorskiego w XVI i XVII w. Gdańsk: Gdańskie Towarzystwo Naukowe, 1966.

Gradowski, Michał. Znaki na srebrze. Znaki miejskie i państwowe używane na terenie Polski w obecnych jej granicach. Warszawa: Fundacja Hereditas, 2010.

Gradowski, Michał and Agnieszka Kasprzak-Miler. Złotnicy na ziemiach północnej Polski, vol. 1: Województwo pomorskie, kujawsko-pomorskie i warmińsko-mazurskie. Warszawa: Ośrodek Dokumentacji Zabytków, Wydawnictwo DiG, 2002.

Gradowski, Michał and Magdalena Pielas. Katalog złotnictwa w zbiorze dokumentacji specjalistycznej Krajowego Ośrodka Badań i Dokumentacji Zabytków w Warszawie, vol. 1. Warszawa: Krajowy Ośrodek Badań i Dokumentacji Zabytków, 2006.

Groth, Andrzej. "Ausschnitt aus der Bewohnerschaft der Stadt Konitz für 1771/1772.” Altpreußische Geschlechterkunde. Neue Folge 34 (2004): 237-244. 
Groth, Andrzej. “Brandgeschädigte in der Stadt Konitz 1742.” Altpreußische Geschlechterkunde. Neue Folge 34 (2004): 245-247.

Groth, Andrzej. “Chojnice w 1749 roku.” Teki Gdańskie 4 (2002): 215-229.

Groth, Andrzej. Małe miasta pomorskie w latach 1772-1806. Słupsk: Wydawnictwo Naukowe Akademii Pomorskiej, 2009.

Herbst, Stanisław. Toruńskie cechy rzemieślnicze. Zarys przeszłości. Toruń: nakł. Cechów Toruńskich, 1933.

Kamosiński, Sławomir. Sadki. Dzieje i współczesność. Bydgoszcz: Wydawnictwo „Koronis", 2009.

Kantak, Kamil. “Kronika bernardynów zamarckich.” Zapiski Towarzystwa Naukowego $w$ Toruniu 6/12 (1925): 174-187.

Kizik, Edmund. "Uwagi wstępne. Prusy Królewskie: środowisko geograficzne, administracja, demografia.” In Prusy Królewskie. Społeczeństwo, kultura, gospodarka, 1454-1772. Szkice z dziejów, edited by Edmund Kizik, 12-32. Gdańsk: Muzeum Narodowe w Gdańsku, 2012.

Kloß, Elisabeth. Das Bürgerbuch der Stadt Konitz von 1550-1850. Danzig: Kommissionsverlag der Danziger Verlags-Gesellschaft, 1927.

Kriegseisen, Jacek. "Słownik złotników gdańskich czynnych w latach 1700-1816." In '...tyżek srebrnych dwa tuziny'. Srebra domowe w Gdańsku 1700-1816, edited by Jacek Kriegseisen and Ewa Barylewska-Szymańska, 155-197. Gdańsk: Muzeum Historyczne Miasta Gdańska, 2007.

Kriegseisen, Jacek. "Złotnicy w małych miastach województwa pomorskiego od połowy XVI do końca trzeciej ćwierci XVIII wieku." In Klejnot w koronie Rzeczypospolitej. Sztuka zdobnicza Prus Królewskich, vol. 1: Eseje, edited by Czesława Betlejewska, 80-84. Gdańsk: Muzeum Narodowe w Gdańsku, 2006.

Krupska, Katarzyna and Bartłomiej Łyczak. "Kontrakty między ks. Janem Ewertowskim a toruńskim złotnikiem Jacobem Weintraubem na wykonanie sreber do kościoła św. Tomasza Apostoła w Nowym Mieście Lubawskim z lat 1711-1728." Biuletyn Historii Sztuki 79/1 (2017): 131-156.

Kucharski, Adam. "Hausen Jan II (młodszy) von.” In Toruński słownik biograficzny, vol. 5, edited by Krzysztof Mikulski, 50-52. Toruń: Towarzystwo Miłośników Torunia, Uniwersytet Mikołaja Kopernika w Toruniu, 2007.

Łbik, Lech. "Z zamierzchłych dziejów sanktuarium Maryjnego w Zamartem koło Chojnic (XV-XVIII wiek)." Rocznik Gdański 60/2 (2000): 13-30.

Łyczak, Bartłomiej. "Artyści grudziądzcy w XVII i XVIII wieku. Część 1: Złotnicy.” Rocznik Grudziądzki 26 (2018): 51-71.

Okoń, Emanuel. “Zabudowa klasztoru cysterskiego w Koronowie w XVIII stuleciu." In Conservatio est aeterna creatio. Ksiega dedykowana prof. Janowi Tajchmanowi, edited by Janusz Krawczyk, 239-263. Toruń: Wydawnictwo Uniwersytetu Mikołaja Kopernika, 1999.

Pałamarz, Piotr and Jerzy T. Petrus, eds. Chojnice, Czersk i okolice. Warszawa: Polska Akademia Nauk, Wydawnictwa Artystyczne i Filmowe, 1979.

Scheffler, Wolfgang. Goldschmiede Ostpreussens. Daten, Werke, Zeichen. Berlin, New York: De Gruyter, 1983. 
Semrau, Arthur. Review of Das Bürgerbuch der Stadt Konitz von 1550-1850, by Elisabeth Kloß. Mitteilungen des Coppernicus-Vereins für Wissenschaft und Kunst zu Thorn 35 (1927): 93-95.

Szweda, Adam, Anna Czapczyk and Barbara Zagórska, eds. Liber Regestrorum in quo proventus ecclesiae parochialis Conecensis tum quoque fructus praepositum eiusdem ecclesiae concernentes ac alia pro meliori successorum informatione memoriae digna fideliter suis locis annotantur, Anno Domini 1738 die prima decembris. Chojnice: Muzeum Historyczno-Etnograficzne, 2001.

Woźniak, Michał F. "Dwie monstrancje osiemnastowieczne w bydgoskiej katedrze." In Kościół katedralny w Bydgoszczy. Studia, edited by Aleksander Jankowski and Dariusz Karczewski, 65-98. Bydgoszcz: Wydawnictwo Uniwersytetu Kazimierza Wielkiego, 2018.

Woźniak, Michał F. Złotnictwo sakralne Prus Królewskich. Studium typologiczno-morfologiczne, vol. 1-2. Toruń: Wydawnictwo Naukowe Uniwersytetu Mikołaja Kopernika, 2012.

Zagórska, Barbara. "Losy złotnictwa parafii farnej w Chojnicach na przestrzeni dziejów w świetle źródeł historycznych.” In Chojnicka bazylika świadectwem wieków. Materiały $z$ sesji naukowej zorganizowanej z okazji jubileuszu 10-lecia nadania chojnickiej Farze tytułu Bazyliki Mniejszej, edited by Hanna Rząska, 33-52. Chojnice: Parafia Rzymsko-Katolicka pw. Ścięcia św. Jana Chrzciciela, 2003. 